\title{
Erythrocyte membrane ATPase activity in Sickle cell crisis
}

\author{
Debapriya Rath', Sudama Rathore ${ }^{2}$, Neha Rani Verma 3 , Neelam B Tirkey ${ }^{4}$, \\ Pradeep Kumar Patra ${ }^{5}$ \\ ${ }^{1,4}$ Assistant Professor, ${ }^{2,3}$ Junior Resident, ${ }^{5}$ Director Professor, Department of Biochemistry, PT JNM MC, Raipur
}

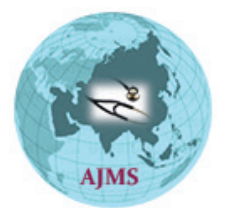

A B S T R A C T

Background: Sickle cell disease is a genetic disease caused by a point mutation in the beta globin gene on chromosome 11 leading to the substitution of valine in place of glutamic acid in beta subunit of globin molecule. The vaso-occlusive crisis, or sickle cell crisis, is a common painful complication of sickle cell disease in adolescents and adults. Many studies have suggested the alteration in intracellular concentration of various ions associated with sickle cell disease. Aims and Objectives: This study aims to evaluate the activity of red blood cell membrane ATPase activity of sickle cell crisis patients in comparison to sickle cell patients in steady state. Material and Methods: Twenty patients of sickle cell crisis were included in the study. Twenty sickle cell patients in steady state were also registered who served as controls. The RBC Membrane ATPase activity were estimated and expressed as $\mu \mathrm{mol}$ of $\mathrm{Pi} / \mu \mathrm{g}$ of protein/hour. Results: The activity of membrane ATPase were found to be significantly high in patients of sickle cell crisis in comparison to steady state ones. Conclusion: Membrane ATPases play a crucial role in the pathophysiology of sickle cell crisis. This study can be a based upon for future studies to understand the pathophysiology of sickle cell crisis and development of diagnostic and treatment modalities for the same.

Access this article online

Website:

http://nepjol.info/index.php/AJMS DOI: 10.3126/ajms.v8i5.17403 E-ISSN: 2091-0576 P-ISSN: 2467-9100

Key words: Sickle cell disease, Crisis, ATPase, RBC membrane

\section{INTRODUCTION}

Sickle cell disease is a genetic disease caused by a point mutation in the beta globin gene on chromosome 11 leading to the substitution of valine in place of glutamic acid in beta subunit of globin molecule. ${ }^{1}$ This point mutation leads to alteration of the physical and chemical properties of the hemoglobin molecule, which is a tetramer of two alpha and two beta subunits. This hemoglobin molecule having mutated beta subunits have a tendency to polymerize and get precipitated in deoxygenated state deranging the normal flexibility of the red blood cell membrane and loss of its concave shape. ${ }^{2}$

The vaso-occlusive crisis, or sickle cell crisis, is a common painful complication of sickle cell disease in adolescents and adults. This is initiated and sustained by interactions among sickle cells, endothelial cells and plasma constituents vaso-occlusion is responsible for a wide variety of clinical complications of sickle cell disease, including pain syndromes, stroke, leg ulcers, spontaneous abortion and renal insufficiency. ${ }^{3}$ Obstruction of blood flow results in regional hypoxemia and acidosis, creating a recurrent pattern of further sickling, tissue injury and pain. The severe pain is believed to be caused by an acute inflammatory response to avascular necrosis of the bone marrow by sickled eythrocytes. ${ }^{4}$

A number of studies have suggested the alteration in intracellular concentration of various ions associated with sickle cell disease. Cellular acidification, cytoplasmic dehydration have also been found in sickled erythrocytes. ${ }^{5,6}$

This study aims to evaluate the activity of red blood cell membrane ATPase activity of sickle cell crisis patients in comparison to sickle cell patients in steady state. 


\section{MATERIALS AND METHODS}

This study was done in the Department of Biochemistry, Pt. J.N.M. Medical College Raipur in collaboration with Sickle Cell institute, Raipur, Department of Medicine, Dr B.R.A.M. Hospital, Raipur and Department of Paediatrics, Dr B.R.A.M. Hospital, Raipur from March 2015 to July 2016. The study has been approved by the institutional ethical committee. Written informed consent was obtained from all the subjects prior to start of the study. The study included 20 cases of Sickle cell disease patients having an episode of sickle cell crisis and 20 age and sex matched sickle cell disease patients in steady state was included as control group.

\section{Inclusion criteria}

Patients of sickle cell disease diagnosed by $\mathrm{Hb}$ electrophoresis and HPLC and having an episode of crisis were included in the study group. Patients of sickle cell disease diagnosed by $\mathrm{Hb}$ electrophoresis and HPLC who had no history of crisis in last one year were included in the control group.

\section{Exclusion criteria}

Patients who had history of blood transfusion within last six months, patients with any other associated hemoglobinopathy or any other co-morbid conditions were excluded from the study.

Two $\mathrm{ml}$ of blood sample was collected from each study subject by phlebotomy in EDTA vials and separated into two parts of $1 \mathrm{ml}$ each. The first sample was used for measurement of complete blood count and the second one for estimation of erythrocyte membrane ATPase activity. The complete blood count was done by using automated hematology cell counter analyzer (Mindray BD - 300 plus).

Measurement of RBC membrane ATPase activity The measurement of RBC membrane ATPase activity consisted of the following steps.

\section{Isolation of RBC from whole blood}

The RBCs were isolated from the other blood components by the help of density gradient separation. GranuloSep ${ }^{\text {TM }}$ GSM 1119, HImedia was used for this purpose. The RBC pellet obtained was washed three times with tris-HCL (100 mM, pH-7.4) containing $100 \mu \mathrm{M}$ EDTA and $1 \mathrm{mM}$ PMSF (phenyl methyl sulfonyl fluoride) and suspended in $1 \mathrm{ml}$ of the same buffer.

Preparation of RBC ghost (haemoglobin free membrane suspension)

The resultant RBCs were then suspended in $10 \mathrm{ml}$ of ice cold Tris- $\mathrm{HCl}(10 \mathrm{mM}, \mathrm{pH}$-7.4) containing $100 \mu \mathrm{M}$
EDTA and $1 \mathrm{mM}$ PMSF (phenyl methyl sulfonyl fluoride) and incubated at $0^{\circ} \mathrm{C}$ for 1 hour. After the incubation the solution was centrifuged at $13000 \mathrm{~g}$ in a refrigerated centrifuge (REMI) at $4^{\circ} \mathrm{C}$ for 20 minutes. The membrane pellet was obtained at the bottom and the supernatant was discarded carefully to minimize the membrane loss. After several repetition of the above steps pearly white membrane pellets were obtained and resuspended in $1 \mathrm{ml}$ of Tris- $\mathrm{HCl}(100 \mathrm{mM}, \mathrm{pH}$-7.4) containing $100 \mu \mathrm{M}$ EDTA and $1 \mathrm{mM}$ PMSF.

\section{Measurement of membrane protein concentration}

The protein content of the membrane was estimated by using Bradford's method. ${ }^{7}$ The standards were prepared using Bovine Serum Albumin and the readings were taken in a spectrophotometer (Elico SL 210 UV VIS).

Incubation of membrane suspension in reaction mixture for ATPase activity

A reaction mixture was made containing $\mathrm{NaCl}(60 \mathrm{mM})$, $\mathrm{KCl}(15 \mathrm{mM}), \mathrm{Mg} \mathrm{Cl}_{2}(6 \mathrm{mM})$ in Tris $\mathrm{HCl}(30 \mathrm{mM}$, $\mathrm{pH}-$ 7.4). One hundred $\mu \mathrm{g}$ of membrane protein made upto $200 \mu \mathrm{l}$ was added to $1 \mathrm{ml}$ of reaction mixture followed by $50 \mu \mathrm{L}$ of the ATP solution ( $5 \mathrm{mM})$. The solution was incubated for 1 hour at $37^{\circ} \mathrm{C}$ for 1 hour. One hundred $\mu \mathrm{l}$ of tricholoroacetic acid is added to the mixture so that the reaction stops. The solution was then centrifuged at $3000 \mathrm{~g}$ for 20 minutes and the supernatant is collected for the estimation of inorganic phosphates in it.

Measurement of produced inorganic phosphate as a result of ATPase activity

The phosphate liberated in the reaction mixture was assayed by a modified method of Chen et al. ${ }^{8}$ The standard curve for $\mathrm{RBC}$ membrane protein assay in all our experiments ranges between 0.1 to $10 \mathrm{mM}$ of $\mathrm{PO}_{4}^{3-}$ The standards were prepared by using $\mathrm{Na}_{2} \mathrm{HPO}_{4}$ in $30 \mathrm{mM}$ tris $\mathrm{HCl}$.

\section{Calculation of ATPase activity-}

The activity of membrane ATPase was expressed in the unit of milli moles of phosphate of phosphate per $100 \mu \mathrm{g}$ of protein per 1 hour.

\section{Statistical analysis}

All parametric values were expressed in the form of mean \pm standard deviation. Microsoft Excel -2007 was used for making the master chart. Unpaired students $t$ test was applied to compare the RBC indices and the ATPase activity between the two study groups.

\section{RESULTS}

The mean age in the sickle cell disease steady state (SS Steady) was 14.2 years and that in the sickle cell disease crisis 


\begin{tabular}{|c|c|c|c|}
\hline Parameter & $\begin{array}{l}\text { Sickle cell disease (steady state) } \\
\qquad \mathrm{N}=20\end{array}$ & $\begin{array}{l}\text { Sickle cell disease (crisis) } \\
\qquad N=20\end{array}$ & $\mathrm{p}$ value \\
\hline Age (years) & $14.2 \pm 3.2$ & $13.8 \pm 3.8$ & $>0.05$ \\
\hline Male $(\%)$ & 60 & 60 & $>0.05$ \\
\hline Hemoglobin (gm/dl) & $8.31 \pm 1.67$ & $8.24 \pm 1.02$ & $>0.05$ \\
\hline Mean corpuscular volume (fL) & $89.38 \pm 5.26$ & $82.01 \pm 7.01$ & $<0.05$ \\
\hline Mean courpuscular hemoglobin (pg) & $29.94 \pm 4.95$ & $27.63 \pm 4.91$ & $>0.05$ \\
\hline $\begin{array}{l}\text { Mean corpuscular hemoglobin } \\
\text { concentration (gm/dl) }\end{array}$ & $31.52 \pm 1.86$ & $33.42 \pm 2.11$ & $>0.05$ \\
\hline Total leukocyte count (thousand/ $\mu \mathrm{L}$ ) & $8.6 \pm 1.2$ & $11.8 \pm 1.6$ & $<0.05$ \\
\hline
\end{tabular}

group (SS crisis) was 13.8 years and both the groups was comparable in the context of age and sex (Table 1). The $\mathrm{RBC}$ indices revealed no significant difference between the steady state group and the crisis group except for the mean corpuscular haemoglobin which was significantly low in the sickle cell crisis patients than those of the steady state ones.

The present study showed Total Leucocyte Count (TLC) of $\mathrm{t} 8.6 \pm 1.2 \times 10^{3 /} \mu \mathrm{l}$ in sickle cell steady group and $11.8 \pm 1.4 \times 10^{3 /} \mu \mathrm{l}$ in sickle cell crisis group. TLC in the crisis patients was found to be significantly higher than that of the steady group. Haynes et al. \& Covas et al. has also reported higher TLC in sickle cell patients. ${ }^{9,10}$ In similar studies conducted by Buchanan et al. also indicated that TLC was greatly increased during vasoocclusive crisis in sickle cell patients. ${ }^{11}$ The increased TLC in sickle cell patients can be attributed to the fact of increased susceptibility of the sickle cell patients for bacterial infection.

The RBC membrane ATPase activity which was expressed in micro moles of inorganic phosphate generated per micro-gram per membrane protein per hour was found to be significantly high in the sickle cell crisis patients than the sickle cell steady state group (Table 2).

\section{DISCUSSION}

Electrolyte concentration in human erythrocytes has been shown to vary with various factors. Decrease intracellular potassium and increased intracellular sodium has been reported on exposure to cold, X-rays, idodoacetate, fluoride. ${ }^{12-14}$ The study of Toterson et al has shown a similar finding in the RBCs of sickle cell anaemia patients when compared to normal individuals. Deoxygenating conditions created in vitro tend to further decrease potassium and increase sodium inside the erythrocytes. ${ }^{15}$ Jason et al in their study have reported an increased activity of $\mathrm{Na}^{+}$$\mathrm{K}^{+}$ATPase in SS patients. ${ }^{16}$ Sickling is also accelerated by transport of $\mathrm{Na}, \mathrm{K}$, and $\mathrm{Cs}$ by non-diffusion, presumed carrier, process and opens pathways for the diffusion of all three ions. ${ }^{17}$ Oubain was found to prevent the rise in MCHC \& reduced the percentage of sickled erythrocytes.

\begin{tabular}{|c|c|c|c|}
\hline $\begin{array}{l}\text { Membrane ATPase } \\
\text { activity }\end{array}$ & $\begin{array}{c}\text { Sickle cell } \\
\text { disease } \\
\text { (steady } \\
\text { state) }\end{array}$ & $\begin{array}{l}\text { Sickle cell } \\
\text { disease } \\
\text { (Crisis) }\end{array}$ & $p$ value \\
\hline $\begin{array}{l}\text { RBC membrane } \\
\text { ATPAse activity ( } \mu \mathrm{mol} \\
\text { of } \mathrm{Pi} / \mu \mathrm{g} \text { of protein/hour) }\end{array}$ & $5.06 \pm 1.01$ & $5.93 \pm 0.83$ & 0.006 \\
\hline
\end{tabular}

These finding indicated a magnified role of $\mathrm{Na}^{+}-\mathrm{K}^{+}$ATPase pump in the pathophysiology of SS erythrocytes. ${ }^{18}$

Increased activity of the ATPases lead to an enhanced rate of ionic outflow from the red cells. Accompanying the ionic outflow the cell also loses a substantial amount of water leading to cellular dehydration. The intracellular dehydration leads to a relative increase in concentration of the hemoglobin facilitating its polymerization and precipitation which plays a pivotal role in the pathophysiology of sickle cell crisis.

\section{CONCLUSION}

Absence of a reliable biomarker to diagnose and/or predict the advent of a crisis episode leaves the doctors with the only option of clinically detecting the disorder which makes the situation even worse. In this study it has been found that the sickle cell crisis patients had a significantly higher erythrocyte membrane ATPase activity than the sickle cell patients in steady state.

A smaller sample size was a limitation of the study. A larger number of study subjects can help making a more generalized notion about the role of membrane ATPase in sickle cell crisis. Further studies may be undertaken to establish the cellular pathways linking membrane ATPase activity with sickle cell crisis.

\section{ACKNOWLEDGEMENT}

Department of Medicine, Dr BRAM Hospital, Raipur (CG), Department of Paediatrics, Dr BRAM Hospital, 
Raipur (CG), Sickle Cell Institute, Chhattisgarh, Raipur (CG).

\section{REFERENCES}

1. Rees DC, Williams TN and Gladwin MT. Sickle-cell disease. Lancet 2010; 376(9757):2018-2031.

2. Ballas SK. Sickle cell anemia: progress in pathogenesis and treatment. Drugs 2002; 62(8):1143-1172.

3. Steinberg MH. Management of sickle cell disease. New England Journal of Medicine 1999; 340:1021-1030.

4. Turnpenny $P$ and Ellard S. Hemoglobin and the Hemoglobinopathies. Emery's Elements of Medical Genetics.14 $4^{\text {th }}$ edition, 2012; pp155-164.

5. Brugnara C. Sickle cell disease: from membrane pathophysiology to novel therapies for prevention of erythrocyte dehydration. Journal of pediatric hematology/oncology 2003; 25(12):927-933.

6. Bookchin RM and Lew VL. Sickle red cell dehydration: mechanisms and interventions. Current opinion in hematology 2002; 9(2):107-110.

7. Bradford MM. A rapid and sensitive method for the quantitation of microgram quantities of protein utilizing the principle of proteindye binding. Anal Biochem 1976;72:248-254.

8. Chen PS, Toribara TY and Warner H. Microdetermination of phosphorus. Analyt Chemistry 1956; 28: 1756-1758.

9. Haynes J, Obiako B, Hester RB, Baliga BS and Stevens T. Hydroxyurea attenuates activated neutrophil-mediated sickle erythrocyte membrane phosphatidylserine exposure and adhesion to pulmonary vascular endothelium. American journal of physiology Heart and circulatory physiology 2008;294(1):H379-85.

10. Covas DT, de Lucena Angulo I, Vianna Bonini Palma P and Zago MA. Effects of hydroxyurea on the membrane of erythrocytes and platelets in sickle cell anemia. Haematologica 2004;89(3):273-280.

11. Buchanan GR, Glader BE. Leukocyte counts in children with sickle cell disease. Comparative values in the steady state, vaso-occlusive crisis, and bacterial infection. Am J Dis Child 1978; 132(4):396-398.

12. Samuel RE, Salmon ED and Briehl RW. Nucleation and growth of fibers and gel formation in sickle hemoglobin. Nature 1990; 345: 833-835.

13. Turnpenny $P$ and Ellard $S$. Hemoglobin and the Hemoglobinopathies Emery's Elements of Medical Genetics $14^{\text {th }}$ Edition. 2012; 155-164.

14. Herrick JB. Peculiar elongated and sickle shaped red blood corpuscules in a case of severe anemia. Arch Int Med 1910; 6:517-521.

15. Hanh EV and Gillespie EB. Sickle cell anemia. Arch Int Med 1927; 39:233.

16. Json G, Samson A and Joy Z. Na+/K+ - ATPase Activity in normal \& sickle cell erythrocytes. Chemistry \& Material Research 2012; Vol 2(5):

17. Tosteson DC, Carlsen E and Dunham ET. The effects of sickling on ion transport. I. Effect of sickling on potassium transport. The Journal of general physiology 1955;39(1):31-53.

18. Izumo H, Lear S, Williams M, Rosa R and Epstein FH. Sodiumpotassium pump, ion fluxes, and cellular dehydration in sickle cell anemia. The Journal of clinical investigation 1987; 79(6):1621-1628.

\footnotetext{
Authors Contribution:

DPR - Concept and design of study, laboratory work, manuscript preparation; SR - Laboratory work, statistical analysis and interpretation; NRV - Laboratory

work, review of literature; NBT - manuscript preparation and critical review of methodology; PKP - Review of study, manuscript preparation.

Work attributed to :

Department of Biochemistry , Pt JNM Medical college, Raipur (CG).

Orcid ID:

Dr. Debapriya Rath: (1) http://orcid.org/0000-0003-1908-2416

Dr. Sudama Rathore: (D) http://orcid.org/0000-0001-7268-7284

Dr. Neha Rani Verma: (t) tt//orcid.org/0000-0002-3447-2300

Dr. Neelam B. Tirkey: (D) http://orcid.org/0000-0002-8691-7367

Dr. Pradeep Kumar Patra: (1) http//orcid.org//0000-0003-4426-0384

Source of Support: None, Conflict of Interest: None declared.
} 